\title{
298 THE JOURNAL OF THEOLOGICAL STUDIES
}

Libraria, Milan, Is.), gives a short introduction and a few notes by Professor Bonfante. A very good English edition with some commonsense remarks on the relations to the Hebrew legislation is by $\mathrm{Mr}$ Chilperic Edwards, The Hammurali Code (Watts \& Co., London, as 6d.). Mr S. C. Boscawen gives a fair renderıng in The First of Emptres (Harper \& Brothers, London, $7 s, 6 d$.), together with a large amount of interesting information about Babylonian life and customs. It is intensely interesting to read, but disfigured by an astonishing number of misprints. Dr T. G. Punches has further given an excellent translation, and some interesting notes in his Old Testament in the light of the Historical Records of Assyria and Babylonia (S. P. C. K., London, 7s. 6d.). An attempt to set out the materials for the history of institutions in Assyria and Babylonia has been made by the present writer, in Assyrian and Babylonian Laws, Contracts and Letters (T. \& T. Clark, Edınburgh, 1 2s.). This work includes a translation of the Code. Mr H. M. Wiener has written a most interesting book of Studies in Billical Law (D. Nutt, London, 2s. 6d.) in which he treats the question from a lawyer's standpoint. He makes excellent use of the Code of Hammurabi. It is a noteworthy attempt to vindicate traditional views of the Hebrew legislation in a modern reading of them. Numerous articles in scientıfic journals notably Ungnad's 'Zur Syntax der Gesetze Hammurabis', Zeitschrift $f$. Assyriologie, 1904, testify to the sustained interest in the subject. It is obviously impossible to do more than chronicle the fact of their appearance.

C. H. W. Johns.

\section{LITURGICA.}

A FULL and interesting sketch of the life and works of the father of modern liturgiology is given in L'Abbé Eusèbe Renaudot by the Abbé Ant. Villien of Tarentaise (Paris, 1904). Apart from his importance for liturgical studies, Renaudot is a very interesting figure by reason of his relations with the persons and events of the latter half of the seventeenth century and the beginning of the eighteenth. He was born in 1648 , of a family which had been protestant. His training he got with the Lazarists at the College de S. Charles, and then at the College de Clermont with the Jesuits, whom as a body he later cordially detested. In $166_{5}$ he joined the Oratory, in the following year received 
minor orders, beyond which he never proceeded, and went to Saumur to pursue theology among the traditions of J. Morin and Thomassin; and there he laid the foundations of his after reputation as 'the most learned orientalist of his day'. He was for a few years a teacher at the Collège de Juilly; but in 1672 he abandoned the Oratory and returned to his home, and his father's position as royal physician gained him entry to the Court and to Bossuet's Petit Concile, where he associated with a brilliant society including Huet, Fleury, La Bruyère, Fénelon and d'Herbelot. He collaborated with Nicole and Arnauld in the Perpétuité de la Foi-and this was the origin of his liturgical interests and studies; he was the constant protégé and ally of Bossuet, whom he assisted in the Variations and in the affairs of Richard Simon, Fénelon and Quietism, and the 'Chinese rites'; and was the author of the opinion on Anglican Orders put forth by Le Quien, and of the traditional argument against their validity. His literary friendships and alliances included those of Mabillon and Montfaucon, Borleau, Racine, and La Bruyère. In 1679 he succeeded his father as editor of the Gazette de France, the prototype of modern journals, founded by his grandfather, and he continued to edit it for the rest of his life. This brought him into close relations with the Court and the Ministers, whom he constantly advised and especially on English affairs and the Court of S. Germain's, on which he became an expert. He was twice disappointed in his hopes of the librarianship of the Royal Library, in spite of the support of Colbert and Le Tellier. He became a member of the Académie Française and the Académie des Inscriptions, and assisted in the revision of the Academy's Dictionary, and contributed a number of memoirs on various subjects. In 1700 he accompaned the Cardınal d'Estrées to Rome as conclavist and was present at the election of Albano, Clement XI, who distinguished him with considerable attentions, and kept hım some time in Rome and consulted him on French affarrs. On his way home, he was entertained and fêted at Florence by the Grand Duke Cosmo III de' Medici, revised the catalogue of his library and was made a member of the Academia di Crusca. In the last twenty years of his life he published his more important works, notably the Défense de la Perpétunté and the completion of the work itself, the Historia Patriarcharum Alexandrnorum and the Liturgiarum orientalum collectio. He and his famly had always had ties with Port Royal and with prominent Jansenists; he was himself the ally of Arnauld and Nicole, and was refused the royal librarianship ostensibly on the ground of his Jansenism; with advancing years he became more and more Gallican and his Jansenist sympathies increased, and after the death of Lous XIV he took a prominent place among the 'appellants and opponents' of the Unigenitus. He died 
September I, I 720 , and was buried at S. Germain des Près. He bequeathed his library to the Abbey: but it perished in the fire of I 794. His character is not very clearly marked in the Abbé Villien's book, but one gets the impression that he was rather stiff and polemical and a little touchy. The second part of the book deals particularly with the liturgical work of Renaudot. A chapter is devoted to a very useful sketch of what had been done up to Renaudot's time; and then his own publications are described, his fundamental ideas on liturgy extracted, and finally a chapter is given to critıcisms, contempoiary and modern, on his work; and in an appendix the liturgical texts which he translated are catalogued. A bibliography of materials for the life is prefixed to the book. Perhaps I may remark that the allusion, on p. 262, note 2, to my Liturgies Eastern and $W_{\text {eslern }}$ may be corrected by reference to p. Ixxil of its Introduction.

It is satisfactory to record that an English translation of $\mathrm{Mgr}$. Duchesne's Origines du Culte chrétien has appeared, as Christian Worship: its origin and evolution by M. L. McClure (London, S.P.C.K., 1903). At this time of day it is needless to bestow either descruption or compliment on Mgr. Duchesne's work, which one is disposed to thınk of as the only real book on 1 ts subject. The translation is well done, idiomatic and readable; and only a few corrections of small details are called for, so far as I have observed. On p. 59, note 1, ' in place of these' makes no sense: I do not know what Mgr. Duchesne's own words mean, and anyhow the remark seems to me to rest on a mistaken interpretation of the text. P. 64, the insertion of 'and' after 'ritual' makes the author use 'ritual' in the slang sense : in fact 'the arrangement of the prayers, their style and general tenor' is the 'ritual'. P. 65, 'Monothelism' is put for 'Monulheietism', p. $7 \mathrm{r}$, 'Eudoxius' should stand for 'Eudoxus'; p. 79, 'non-liturgical service' is misleading in English, the meaning being 'a service other than,' or ' not including, the indss'; p. I 39, note, 'Felton' should be 'Feltoe'; p. 237 sq., read 'Asian', 'Alexandrıne' for 'Asıat', 'Alexandrian'; p. I69, for áкроoті́кıа read áкробті́ха; p. 379, 'tunıcle' is a singularly unfortunate rendering of 'tunique' in the sense of 'alb'; p. 431, 'Leonine' not 'Leonian' is usual and correct; and p. 447, de zeiunizs is the right expansion of de ieiun. If I may make a few suggestions as to Mgr. Duchesne's own work p. 6i, note, is not the reason the 'Clementine' preface ends with Joshua and the Conquest of Canaan, that this corresponds typically with the Ascension in the post-sanctus (cp. Heb. iv 8, 14)? P. 67, the Liturgy of S. James, so far as I could learn by enquiry on the spot ten years ago, is not in use in Cyprus, and its restoration in Jerusalem is very modern : p 75, Dmitriewskij, not Wobbermın, discovered and first published the Serapion document, in which also more than two 
prayers are ascribed to Serapion; p. 156, a reference would be useful to Dr McCarthy's edition of the Stowe Missal (Trans. Royal Irish Acad. xxiil, Nov. 1886), which is better than Mr Warren's ; p. r68, it is the author of the Apostolic Constitutions who has obviously manipulated the text of the Gloria in excelsis, while the Latin text corresponds closely to the original Greek; p. 168 , the O. T. lesson in the Byzantine mass is implied also in S. Maximus Mystagogia, while it is surely not the case that the Alleluia before the Gospel is peculiar to the Roman rite, since it is practically universal in the East; p. 233, a reference to Dom Morin's article (Rev. Benéd. Aug. I 897 ) on the origin of the Embertides would be in place; p. 336 sq., Dr Wilpert seems to have shed more light on the origin of certain vestments; and p. $5 \mathbf{2 4}$, a reference to Dr Riedel's translation of a new text of the Hippolytean canons (Die Kirchenrechtsquellen d. Patriarch. Alex. p. 200) would be useful.

Two more volumes of the Alcuin Club Collections have appeared. Vol. v is Mr Percy Dearmer's Dat Boexken vander Missen: 'The Booklet of the Mass': by Brother Gherit van der Goude, I $5 \circ 7$ (Longmans, r903). Mr Frere identified the original of 'L'interpretation et signification de la Messe (Anvers, I 529)' used by Dr Rock in The Church of our Fathers as Dat Boexken vander Missen of Gherit van der Goude, of which there are three editions in the British Museum; and Mr Dearmer further found in the Museum an English version, The Interpretatyon and Sygnyfycacyon of the Masse by Frère Gararde, 1532. He has here edited the liturgical parts of the second book of the Booklet, consisting of thirty-three woodcuts of the successive actions of the mass accompanied by a short description of them. Since Gherit was an Observantıne Franciscan and used the Roman use, Mr Dearmer treats the woodcuts as evidence of the Roman ceremonies of the beginning of the sixteenth century, when the rubrics of the Missal are insufficient as a description of what was done; and he comments on each picture, indicating its points, and illustrating them by the help of the Indutus planeta, the Alphabetum sacerdotum and such rubrics as are available. The pictures are very interesting and cover much more ground than the series already published by the Alcuin Club in Vol. li of its Collections: the editor's comments are good and to the point. But there are too many misreadings or misprints: I have noticed them on pp. 13, 17, 25 (two), 39 (two), 40, 43 (three), 71, I I5, I35 (two). In two appendices are given the relevant parts of the English version of $\mathrm{I}_{532}$, and the Ordinary and Canon according to the use of Utrecht (1540). Vol. vi is Mr Cuthbert Atchley's The Parish Clerk and his right to read the liturgical Epistle (Longmans, I903), in which, in a more or less popular form, the author traces the origin of the parish 
clerk and effectively proves his thesis, at least by authoritative precedent from the sixteenth century onwards.

The same subject is dealt with on a larger scale and with full detail in the introduction to The Clerk's Book of 1549 edited by Dr Wickham Legg for the Henry Bradshaw Society (London, 1903). The two books are not independent of one another, since Dr Legg would have us understand that his material is chiefly due to the researches of Mr Atchley. The text introduced is derived from a untque copy in the British Museum, and consists of the 'Book of Common Prayer' of 1549 (i. e. what appertains to the Divine Service), the Litany, and 'all that shall apperteigne to the clerkes to say or syng' at the Liturgy, Matrimony, Visitation and Communion of the Sick, Burials, Churchings, and Commination. In a series of appendices are collected a number of documents bearing on the duties \&c. of parish clerks ; and the whole is concluded with a body of short notes and a general index.

Since our last Chronicle, the Henry Bradshaw Society has also issued four other volumes. First, the Benedictional of Archbishop Robert (1903), edited by Mr H. A. Wilson. This, an Englss Benedictional and Pontifical combined, written in the latter part of the tenth century at the New Minster of Winchester, and taken to Rouen probably before $105^{\circ}$, where it became the property of the Chapter and where it is now preserved in the Public Library, is familiar enough by name and in part by contents, but has never before been printed at length. In his introduction Mr Wilson considers the MS and its character and early history, the identification of Robert-whether Robert of Jumièges, Archbishop of Canterbury († $1 \circ 70$ ), or Robert of Normandy, Archbishop of Rouen (990-1037) and maternal uncle of S. Edward the Confessor - and discusses its relations to other English Pontificals; and in his notes he developes the comparison in detail. Sir E. Maundc Thompson has edited Customary of the Benedistine Monasteries of Saint Augustine, Canterbury, and Saint Peter, Westminster, Vol. 1 (London, 1902). This first volume comprises the text of the Canterbury book contained in the Cotton MS Faustina c. xil, which is to be followed by what remains of the Westminster book contained in Cotton MS Otho c. xi, and another, early, customary of S. Augustine's Canterbury contained in MS 2 I I of Gonville and Caius College. In the Preface the Editor describes the Canterbury MS and shortly catalogues its contents, reserving further remarks for the second volume. Mr W. H. Frere and Mr L. E. G. Brown have so far completed a weary ten years' work as to have brought out the first volume of the Hereford Breviary (London, 1904) containing Psalterium, Commune Sanctorum and Temporale. The text is that of the 
printed edition of $\mathrm{I}_{5}{ }^{\circ}$, with the variants of the thirteenth-century MS Breviary at Hereford, the fifteenth-century MS at Worcester, the fifteenthcentury Bodleian Psalter, and the fourteenth-century Ordinal in the British Museum, added in the margin. Happily and wisely the editors have not printed the text in full, but where it agrees with that of the Sarum use have made reference to Proctor and Wordsworth's reprint of the latter. In Tracts on the Mass (London, 1904) Dr Wickham Legg has edited, in whole or in part, eleven documents, being on the ceremonial of the mass, according to various uses, from the thirteenth to the sixteenth century; viz. two Sarum Ordinaries of the thirteenth and fifteenth centuries respectively, Langforde's Meditations (fifteenth or sixteenth century), a Carthusian Ordınary (Englısh, fifteenth or sixteenth), Alphabetum Sacerdotum (French, fifteenth and sixteenth), an Ordinary of Coutances (sixteenth), a Dominican Ordinary (French, thirteenth), Praeparatio Sacerdotis (Italian or French, fifteenth), Burchhard's Ordo Missae (Roman, 1502 ) - which appeared in Roman Missals from 154I-1558, and probably suggested the Ritus celebrandi of the Pian Missal,-Indutus planeta (French, sixteenth) and L. Ciconiolanus Dire. ctorium divinorum officiorum (Roman, sixteenth). To several of these Dr Legg appends other lllustrative extracts; in an introduction he describes the origin and history of the tracts; and at the end comments on them in forty pages of notes.

The French Congregation of the Benedictines, under the leadership of Dom Fernand Cabrol and Dom Henri Leclercq, have inaugurated a vast, even appalling, undertaking, and one worthy of its great traditions, in Monumenta ecclesiae liturgica, two parts of which have already appeared. It is intended to include the publication or republication of everything related to liturgy, Western and Eastern, up to the ninth century, not excluding even Biblical Versions. The first volume, of which the first section has been issued, is Reliquiae liturgicae vetustissimae ex SS. Patrum necnon scriptorum ecclesiasticorum monumentis selectae I (Paris, Firmin-Didot, I900-I 902), by the editors themselves, consisting of a collection of the passages bearing on liturgy and its discipline from all Greek and Latin sources-the New Testament, ecclesiastical writers, martyrdoms, Church Orders, inscriptions, \&c.from the Apostolic Age to the Peace of the Church, quoted as fully as is necessary, and arranged according to the geographical distribution of the sources and following the accepted order of the works of the several writers. It is a work which very much needed doing, and every one interested in liturgical origins and early history will be grateful for it. The geographical arrangement is wholly to be commended: the practical neglect of local differences is a defect e.g. in Bingham's great work. Dom Leclercq's introduction covers a large area of varied 
ground : his analytical table of the passages commented on in Origen's homilies and the references in them to 'lessons', with a view to the determination of the lectionary-system implied, and the comparison of those on the Pentateuch with the Jewish system, is a specimen of the sort of careful work he has done and of the sort of work that wants doing elsewhere, if the origins of lectionaries are to be studied. It is impossible at this moment to give any adequate appreciation of the volume: it is a laborious collection of materials, and it is only by long use that one will be able to appreciate it fully. There are two criticisms in detail I would venture to make. The first relates to the form of part of the volume. A large $4^{\circ}$ page, of 59 lines $6 \frac{1}{4}$ inches in length, of modern Latin in rather small print on glossy paper, makes an unnecessary demand on eye and nerve. It would be a great relief if in future the editors could see their way at least to dividing the pages into two columns throughout. And secondly, it is not clear why the material supplied by the Apostolic Constitutions is included in this volume. As it stands it belongs to the second half of the fourth century and probably to the last quarter. Of course it incorporates older material, but there is no attempt here to distinguish the grounddocuments from the interpolations which form the greater part of the matter; and the Didaskalia is not otherwise represented in this volume.

The fifth volume, the second to be issued, is Le Liber Ordinum en usage dans $I$ Eglise Wisigothique et Mozarabe d'Espagne du cinquieme au onzième siecle (Parıs, Firmin-Didot, 1904), and its publication is an important event for liturgical studies. The Mozarabic Manuale, or Rituale, and Pontificale, a combination of which forms the Liber Ordinum, have hitherto been practically unknown: but Dom Marius Férotin, the present editor, has found four MSS of the book, of the eleventh century, three at Silos and one at Madrid; and one of them, the Silos MS of ro52, he shews reason to believe to be the copy which was sent to Alexander II for his scrutiny in c. 1065, when the suppression of the Mozarabic rite was proposed. The text of this MS is the basis of the present edition, the others supplying further matter as well as the variants digested in the apparatus criticus. In a lucid Introduction Dom Férotin fully describes the MSS, and in Appendices he gives, (1) nine Mozarabic kalendars; (2) a collection of material for the reconstruction of two pontifical rites not represented in the books, viz. the unction of kings and the dedication of churches; $(3)$ the forms of denunciation of feasts ; (4) a curious Horologion contained in some of the MSS, being a table by which to determine the time of day in the several months of the year by the length of the shadow of the human body; (5) various forms of doxology. The whole 
is supplied with four admirable indexes, biblical, philological, liturgical and general. At present one can say nothing in detail, but only express gratitude for the new field opened up and the hope of opportunity to explore it. The description of unpublished Mozarabic material given at the beginning of the Introduction makes one's mouth water.

Dom Cabrol, with a list of thirty-nine distinguished collaborators, is also engaged on another great undertaking, the Dictionnaire d'archéologie chrétienne et de liturgie (Paris, Letouzey, 1903, 1904). The scale of it can be estimated from the fact that, in the five fasciculi and $\mathrm{r}_{504}$ columns already published, it has reached the middle of the article AME. It deals with liturgiology on all sides-ritual, ceremonial, music, ministers, language, apparatus, kalendar, biography, palaeography: and to its own treatment of the subject-matter, it adds elaborate bibliographies; and it is copiously illustrated throughout. There are some thirty-two articles so far on liturgical matters; the most important are those on the African (Cabrol), Alexandrine (Leclercq) and Ambrosian rites (P. Lejay), and they seem to be excellently done and practically to cover the ground so far explored.

Dr Ant. Baumstark continues the perpetual discussion of the origin and development of the Roman canon in Liturgia Romana e Liturgia dell Esarchato (Rome, 1904). After summarizing and criticizing the theories already proposed, he discusses the 'fundamental questions' of the structure of the eucharistia and its several types ; and then developes his own theory of the history of the Roman eucharistia or canon missae. The result he reaches is that the original Roman was related to the Syrian type, and consisted of a Praefatio of thanksgiving for creation, Sanctus, Post-sanctus (Cum qubus et nostris .., Vere sanctus) consisting of a thanksgiving for redemption and culminating in the Qui pridie, followed by Unde et memores, Te igitur (In which occurred an Invocation), Memento, Communicantes, Memento etiam and part of Nobis quoque. That this was combined by S. Leo the Great with another type of canon (which Dr Baumstark argues to have been that of Ravenna) to which belongs Hanc igitur (in the extended intercessory form found in one or two sources), Quam oblationem, Sanctum sacrificium, Supplices te and the rest of what is now Nobis quoque, including the list of Saints. Finally this composite and partly reduplicated formula was rearranged and retouched by S. Gregory the Great, and so took its present shape. This result is reached by an elaborate argument; but, on a single reading at least, the argument scarcely leaves a sense of conviction. Dom G. Morın has dealt with it with some severity in Revue Bénédictine, Oct. 1904.

Dr Jos. Freisen, Professor of Canon Law at Paderborn, has pubVOL. VI. 


\section{THE JOURNAL OF THEOLOGICAL STUDIES}

lished (Paderborn, 1904) three Scandinavian service-books, the Manuale Lincopense (Linkoping) of $\mathbf{1 5}_{52} 5$, the Manual portions of the Breviarium Scarense (Skara) of 1498 , and the Manuale Aboense ( $\AA$ bo) of 1522 ; with an introduction dealıng with the Manuals, Breviaries and Missals of some Swedish and Norwegian dioceses, among them the Upsala Missal of 1483 , which is not mentioned in Weale's Bibliographia Liturgica, and some notes. Dr A. Schonfelder, in the first volume of a new Liturgische Bibliothek (Paderborn, 1904), prints the text of the Benedictional of Meissen of 1512, the Agenda of Naumburg of 1502, and the Ritual of Cologne of 1485, with an introduction. The origin of Luther's Litany of 1529 , which was largely drawn upon in Marshall's Primer of 1535 and Cranmer's Litany of $\mathbf{I}_{544}$, has never been explained; it does not look like Luther's composition and its origin ought to be found in the litanies of the Saxon dioceses. It is notable therefore that in the short litanies of the Meissen and Naumburg books (pp. 15, 56,70) there is one coincidence in the suffrage 'Per mortem et sepulturam tuam'. The normal litanies are not contained in these books or we might find more to the point. Mons. P. M. Lafrasse, honorary canon of Annecy and professor at the diocesan Seminary, has treated elaborately of the diocesan use of Geneva in comparison with Roman usage, in Etude sur la liturgie dans Iancien diocese de Geneve (Geneva, I 904). He catalogues and describes the MS sources, and describes a printed Missal of 1508 not mentioned in Weale. I have not seen Das Rituale von St. Florian aus dem zwolften Jahrhundert, edited with introduction and elucidations by Ad. Franz (Freiburg i. B. 1904); but from a notice of it by M. Paul Lejay in Bulletin critique 19 Dec. 1904, I gather that, having in view a work on German Ritualia, the editor here prints the text of the monastic Rituale of S. Florian in Austria, an interesting feature of which is an Ordo catechumenorum of the type of those of the Ordines Romani but providing for only three scrutinia. In the introduction the editor describes another monastic Rituale, that of Lambach, of the same age; and he comes to the conclusion that, in Germany at least, secular Ritualia are much later in date than monastic.

Mr G. W. Hart and Mr W. H. Frere have reissued Dr D. Rock's The Church of our Fathers (4 vols. London, Hodges, 1903-4), making little change beyond improving the references, adding largely to the illustrations, and in a postscript noting the points requiring correction or supplement, and prefixing a short biographical notice of the author by Father B. Kelly.

The new Library of Liturgiology and Ecclesiology for English Readers, edited by Mr V. Staley, Provost of Inverness (London, De La More Press, 1902-1904), is a series of well-printed and convenient volumes, 
of which five have so far appeared, with short prefaces by the editor, giving all necessary explanation of authorship and sources. Vols. I, III, $\mathrm{V}$ are a reprint of the Hierurgia Anglicana, originally edited ( $1843^{-8}$ ) by members of the Cambridge Camden Society, and now re-edited by Mr Staley himself, who has re-classified the material, very largely increased it, omitted superfluous and unimportant passages, and added to the original illustrations a large number of photographs which are interesting and useful but generally not very good as photographs. The second volume is The First Prayer Book of King Edward VI, a reprint of Whitchurche's issue Mense Martii. It is described in the preface as a reproduction 'verbatim et literatim', a description which might well have been truer than it is. The relations of types might have been better preserved: e.g. in the present volume the titles of the days in the de Tempore and the Sanctorale are in black letter, and 'Collect', 'Epistle' and 'Gospel' are in capitals : whereas in the sixteenth-century texts-I have only the June issue of Whitchurche before me, but I do not think in this respect it differs from the March issue-the titles of the days are in the type of the text, and 'Collect' \&c. in that of the rubrics. Again, in the original prints only one letter after the large initial of paragraphs is in capitals, and ' $\&$ ' is as common as 'and', and ' $\&$ c.' is perhaps uniformly used; while in the reprint, the whole of the opening words is printed in capitals, and ' $\&$ ' and ' $\& \mathrm{c}$ ' are always, so far as I observed, expanded into 'and ' and 'etc.' These small details disguise the fact that the English books were printed in the same form as the contemporary Latin books, except that a small type was used instead of red in the rubrics. The fourth volume of the series is a collection of Essays on Ceremonial-viz. 'English Ceremonial', 'On English liturgical colours' and 'Some remarks on the Edwardian Prayerbook', by Mr Cuthbert Atchley; 'On some ancient liturgical customs now falling into disuse', by Dr Wickham Legg ; 'Church vestments' and 'The altar and its furniture', by Mr Percy Dearmer; and 'The genius of the Roman rite', by Mr Edmund Bishop. Some of these are reprints and are already known; the character of others can be conjectured ; and Mr. Atchley's 'Remarks on the Edwardian Prayer-book' recounts again the pitiable story of the years 1549-1552. For my own part, I cannot but wish that ecclesiastics would find other means of illustrating treatises on vestments than by portraits whether of themselves or of other clergymen.

The Scottish Church Service Society has issued an excellently printed and very convenient edition of the Book of Common Prayer of 1637 (Edinburgh, Blackwood, 1904), edited with introduction and notes by Dr James Cooper. The introduction is interesting and among other things deals at some length with the relation of Laud to the production 
of the book and disposes of the legend of his responsibility for it. In an appendix to the introduction are printed Laud's letter to Wedderburn ( $\left.{ }^{6} 3_{6} 6\right)$, Mr Hill Burton's collation of the Lambeth Prayer Book in which Laud noted the changes made in the Scottish Book, and a detalled account of Charles I's autograph entries of 'the latest alterations and additions approved' by hım, contained in a Prayer Book now belonging to Lord Rosebery. The notes deal chiefly with the relations of the Scottish Book to the successive revisions of the English and to the presbyterian orders of service, and with contemporary criticisms on the book of 1637 . In Note $E$ there is a curious slip: it is there said that unt1l I66I not 'a word was said' in the Englıs book about the use of the Exhortation, Confession, \&c., at Evensong ; whereas in fact from 1552 onwards the direction for their use both at Matins and Evensulng was given in the first ruhrir of Matins. In note $\mathrm{F}$ it is said that in the rubric before Quicunque vult, which in this respect is identical with the English rubric as it stood from I 549 to I66I, it is 'mplied' that the Quicunque is to be said instead of the Apostles' Creed ; whereas there is no such implication and for all that is said or implied to the contrary the ordinary use of Prime, in which both are sald, is continued. And further on in the same note (p. 246) the Ember prayer Almighty God the Giver is held to be 'probably composed by Archbishop Laud'; whereas it is only a slightly varied form of the Ordination collect of I $55^{\circ}$ and onwards. It need scarcely be said that Dr Cooper is thoroughly appreciative of the book and recognizes its superiority to the English book.

In the Corpus scriptorum christianorum orientalium, Mons. H. Labourt has edited the text, with a Latin translation, of the Expositio liturgiae of Dionysius bar Salıbi (Paris, 1903), which gives valuable evidence of the stage of development reached by the Monophysite Syrian mass in the twelfth century. An extract of the Expositio is given by J. S. Assemani in Btblotheca orientalts ii pp. 176 seq., and the tract attributed to John Maro, of which J. A. Assemani gives a Latin version in Codex liturgicus v pp. $227 \mathrm{seq}$, is a Maronite interpolation of Dionysius; but, so far as I know, Dionysius's own text has not been published before. The publication of the whole series of Eastern commentaries on rites is desirable if their development is to be traced in detarl.

In Die nestorianische Taufliturgie (Gressen, 1903), Dr G. Diettrich gives a German translation of the Nestorian baptismal rite, following the text published by the Archbishop of Canterbury's Mission (Urmi, I 890), and comparing it with that of eight MSS at Berlin, Rome, the Britısh Museum and Cambridge. The authorship of the rite, 1.e. of the revision of the original rite to accommodate it to the baptism of the children of Christian parents, is attributed on good grounds to the 
Patriarch Ishoyabh III of Adiabene; and in his introduction and notes Dr Diettrich attempts by the excision of later additions and some rearrangement, to recover the rite as Ishoyabh left it ; and his reconstruction seems probable, and at least he brings out the essential features and movement. The rite is unique in containing no exorcisms, renun-

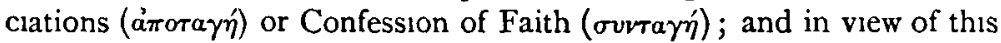
and of the character of some of the paragraphs which must be attributed to the reviser, Dr Diettrich argues with plausibility, that the character of the revision was in part determined by the Pelagianism of the Nestorians. His strange interpretation of the baptismal 'offertory'-i.e. the part of the rite relating to the oil and the water, corresponding to the offertory in the liturgy of the mass, on the scheme of which the baptismal office is constructed-as implying an offering of our Lord in His Baptism, which is here commemorated and reproduced, can only be regarded as a jeu d'esprit, founded moreover on an obvious mistranslation; and his contention that the transubstantiation of the water is implied, is based on a very obscure phrase, which by no means necessarly implies it. I gather from Dr Funk's notice of the book in Theol. Quartalschrift, Jan. 1905, that this last point has been criticized at length by Dr Baumstark in Oriens christianus iii pp. 219 seq.

Mr C. F. Rogers's Baptism and Archaeology, being Part 4 of Vol. v of Studia biblica et patristica (Oxford, r903), is an investigation of the method of the administration of baptism by the evidence of early pictorial representations and by measurements of existing early baptismal fonts; and he reaches the conclusion that the ordinary method both in East and in West was, not submersion, but affusion or rather perfusion-1.e. by pourng water over the head of the neophyte as he stood in water; and that submersion only came into any widespread use in the ninth century, apparently on the ground of a literal but perhaps not strictly necessary interpretation of the figure of burial used by St Paul (Rom. vi \&c.). He reproduces and examines all the representations he has found both of our Lord's Baptism and of baptism in general in successive periods down to the ninth century, and a certain number of early texts, and gives detailed descriptions and measurements of a large number of fonts, a great proportion at least of which would seem not to admit of the possibility of submersion. The monograph might be described as a detailed commentary on Mgr. Duchesne's remarks, in Églises separées pp. 89 seq., in answer to the Encyclical of the Constantinople Synod in 1895. Demonstration is no doubt impossible; the earliest evidence is exclusively Roman and for the earlest period there is practically no direct evidence; but Mr Rogers goes a long way towards proving his contention; and he forestalls the critucism that the traditional representation is only the result of the 
difficulty of representing submersion; though perhaps in some cases it still needs considering whether the representation may not be merely of a moment in the process of submersion; e.g. in fig. 36 . The evidence is at least sufficient to dispose of the quarrel which the Orthodox Easterns on occasion still keep up against the practice of the West. A table of contents would be useful; or failing this, the headlines might be varied. To the list of fonts on p. 354 may be added those of S. Frediano at Lucca and S. Giovanni in Fonte at Verona, both of the twelfth century. 'Ravennate', not 'Ravennese', is the adjective belonging to 'Ravenna'.

Father F. W. Puller's The Anointing of the Sick, issued by the Church Historical Society (London, S.P.C.K., I904), is a very useful and characteristically careful and thorough piece of work. Its main object is a dogmatic one-to shew that the sacramental conception of Unction, as conferring sanctifying grace ex opere operato, is not original and did not preval till the ninth century: with this we are not here primarily concerned. But naturally the book contains a good deal of matter touching liturgy. Fr. Puller first examines St Jas. v 1 3-16 and shews that the early commentators, and some later ones, no doubt rightly, interpreted it as referring to two distinct things, and not only one-viz. to Unction and to Penance; i. e. first, the sick is to be anointed, with prayer, with a view to recovery; and secondly, if he has committed grave sins, he is to be absolved on confession; and he traces the tendency to confuse the two and to make remission of sins part of the effect of unction. He then examines the forms of conferring unction in liturgical documents, from Serapion onwards : and adds a valuable collection of instances of the use of unction from the second to the ninth century. The following chaptcrs $v$-viii belong to the dogmatic aim of the book : but ch. vii, on the number of the Sacraments, may be noted un passing. Ch. ix is a judicious discussion of the desirability of formally restoring Unction in the Anglican Church. Of the five appendices, the first is a collection of liturgical forms related to the Unction of the Sick, and the third discusses the forms of exorcizing and blessing oil in the Bobbio Missal ; the second is a careful examination of Syriac evidence in the fourth to the sixth century; the fourth gives the relevant sections of the second Capitulary of Theodulf of Orleans ; and the last the Trudentıne decree. To the instances of bread blessed for the sick, to which Fr. Puller several times refers, may be added the Benedictio panis ad infirmum in the Ponttical of Egbert. Why are S.P.C.K. books so uniformly unsightly?

Mr H. L. Dixon's 'Saying Grace' historically considered (Oxford, Parker's, 1903) is a useful catena of passages on the benedictio mensae, including pagan, Jewish, and Moslem, as well as Christian evidence, 
and a collection of forms from the fourth century downwards. It is especially satisfactory to have the Graces of the Colleges of Oxford and Cambridge and of the Public Schools collected in so convenient a form. The editor does not notice that the Oriel Grace Benedicte Deus qui pascis is only a translation of that of Ap. Const. vii 49 and of the Syrian monks which he quotes (p. 88) from S. Chrysostom; itself nearly related to a passage in the great intercession of the liturgy of S. Mark.

The Vatican Studi e Testi I 3 : Catalogo sommario della Esposizione Gregoriana (Rome, 1904) is a catalogue of the Vatican MSS of Lives of St Gregory the Great, Sacramentaries and Missals, specimens of Musical Notation and works on Music, exhibited during the Gregorian Commemoration in April, 1904. The most important of these is apparently the third section, being specimens of musical notation earlier than $135^{\circ}$ arranged according to their geographical distribution; and the editors acknowledge their indebtedness to $\mathrm{Mr} \mathrm{H}$. M. Bannister for his assistance in selecting and describing them.

The Benedictines of Solesmes continue their Palkographie musicale, and in 1903 and 1904 have issued Nos. 57-64 (Tournay: Desclée, Lefebvre \& Cie.).

Dom Ambrogio Amelli, Prior of Monte Cassino, has edited a text of the Micrologus of Guido of Arezzo (Guidonis Monachi Aretini Micrologus ad praestantiores codices MSS exactus Romae 1904), in fulfilment of a purpose announced more than twenty years ago, abandoned through the discouragement given to the rectification of the tradition of ecclesiastical music, but revived by the recent Instruction of Pope Pius X. One learns from the preface that the text of Guido was sadly in need of reconstruction; and the present edition is the result of a collation of nineteen MSS, of which a list is given on p. II. It represents only results, giving the reconstructed text without apparatus; but it is intended to be coordinate with a scientific edition, to extend to the whole works of Guido, which will contain an apparatus criticus. L'Apostolato della musica nel secolo xx, per un Solitario (Monte Cassino, I 904 ) is a devout meditation and a cry of triumph on the reformation promised by the Pope's Propriomotu, and gives evidence of the acuteness with which the previous discouragement of a purification of the musical tradition has been felt by some in Italy.

Mr Edward Dickinson's Music in the History of the Western Church (London, Smith, Elder \& Co. 1902) is a clear and interesting account of the developement or revolution in ecclesiastical music which has resulted in the present situation. Of the quality of the musical technicalities and criticism I am unable to judge; but the story is inteligible apart from these. Remarks here and there do not inspire 
confidence in the author's command of general history or knowledge of ritual matters. But perhaps a chief interest of the book in the present connexion is that it may be said to be a confession or a demonstration, however unintentional, of the incompatibility of modern socalled ecclesiastical music with the purpose it is made to serve. Mr Dickınson asserts over and over again in one form or anotheron this point he is, as he would himself say, presumably in the American language, 'repetitous' - that the difference between ancient and modern music is, that whereas in the former the music is subordinate to the text and follows rhetorical laws, in the latter 'it strives to emancipate itself from the thraldom of word . . . and to exalt itself for its own undivided glory' (p. 18 ), 'the music is paramount, the text is accessory' (p. 97 : cp. pp. 40, 99). Yet he does not draw the obvious conclusion. He recognizes the arm of the real ecclesiastical music, that it exists 'not for the decoration of the offices of worship . . . but rather for edification, instruction, and inspiration' (p. I75); that it expresses not individual feelings, but the temper of the Church as such, 'the mood of prayer, . . . and that not the prayer of an individual agitated by his own personal hopes and fears, but the prayer of the Church, which embraces all the needs which the believers share in common' (p. 198: cp. p. 69); he recognizes the beauty of Plain Song and that it merits the reverence which is given to it-its melodies 'have maintained for centuries the inevitable comparison with every other form of melody, religious and secular, and there is reason to believe that they will continue to sustain all possible rivalry, until they at last survive every other form of music now existing' (p. 10o); and that the result of the mediaeval developement up to its climax in the sixteenth century was 'the most complete example in art of the perfect adaptation of means to a particular end ' (p. 179); he recognizes also the opposition of the religious mind to the intrusion of developed musical art into worship (p. I8), and that the breaking of the ccclesiastical tradition in the seventeenth century was 'an outcome of the Renaissance secularization of art' (p. 93), coming about 'as soon as the transformed secular music was strong enough to react upon the Church' (p. I 79), with the result that the Renaissance 'transformed the whole spirit of devotional music by endowing religious themes with sensuous charm and with a treatment inspired by the arbitrary will of the composer and not by the traditions of the Church' (p. 197), and substituted individualism for universality; and he is quite alive to the defects of the Anglican so-called chant (p. 340 sqq.). Yet he takes it all very quietly and seems to have no misgivings.

Dr A. M. Richardson, the Organist and Choir Director of S. Saviour's, Southwark, has published two small books on ecclesiastical music; 
Church Music in the series of Handbooks for the Clergy (Longmans, 1904) and The Psalms: their structure and musical setting (London, Vincent, 1903). The first is a general practical manual. The historical sketch in chap. ii is quite second-hand and amounts to little and might have been omitted: and some of the historical statements throughout the book are more curious than true. The tone of Dr Richardson's advice to choirmasters is excellent. The practical directions are sensible and will be useful; but in respect of recitation they are sometimes wrong; and the insistence on the pronunciation of all consonants will tend, whether Dr Richardson means it or not, to encourage the shocking practice sometimes met with, which sets the teeth on edge, and is neither English nor endurable. In English in fact all consonants are not fully sounded, but some are practically elided: 'and to' and 'send down', rendered as Dr Richardson's directions will inevitably be understood, are merely intolerable. And Dr Richardson certainly at some points travels outside his sphere; the musician as such has no jurisdiction over the interpretation of the text or over ritual dispositions, and excursions into such regions are irrelevant to the theme, even if the directions are right in themselves, which here is not always the case. And with reference to this, it seems well to remark, in view of what is said on p. I39 and of other things, that the Lambeth Judgement, whatever its value may be, did not allow the Benedictus, but allowed the Agnus Dei on grounds which obviously exclude the Benedictus as commonly used. Dr Richardson's attitude to Plain Song, which he calls 'the crabbed and old-fashioned work of a bygone age', is intolerant and undignified. It is currous that the song of the greater part of Christendom at the present moment should be described as obsolete; and Dr Richardson's argument that Plain Song is characteristically neither religious nor Catholic, whatever the merits of the case may be, would prove equally well that a chasuble is not a sacred vestment and that he himself is not a Catholic.

Dr Richardson's second book, The Psalms, is essentially a criticism on 'the maltreatment of our beautiful language', the 'outrage upon good taste and common sense', the 'terrible artistic monstrosity known to many as "Anglican Chanting". And here in effect he draws much of the sting of his criticism on Plain Song, since he grants and urges that there is but one legitımate system of chanting and that a real chant has no fixed time or accent. If this is granted, scales and melodies become comparatively unimportant, so long as the melodies are religious and congruous and are kept within a sober compass, which is not the case with a large number of 'Anglican chants'. But it may be noted as curious that among his distinctions between the ancient tones and Anglican 'chants', he does not include the constant 
change of the reciting note in the latter. A true chant, I conceive, is constructed on a single line, as it were; whereas in most Anglican 'chants', the reciting note is varied at every half verse. Apart from this, it is to be hoped that Dr Richardson's criticisms and instructions will be taken to heart; and that his little commentary on the Psalter will suggest to organists and choirs that the Psalter must be studied and understood, if it is to be properly recited. I do not remember that Dr Richardson has said what it would be well if he would say, that a real element in choir practice ought to be the intelligent and deliberate reading of the Psalms, without note. Dr Richardson's scheme for a sort of dramatic rendering of the Psalms, with continually varying melodies and so on, is quite another matter. It might be all very well for occasional use at solemn matins and evensong, but not for every day and twice a day; and it is not clear that in all respects it is consistent with the pointing of the Psalms 'as they are to be sung or said in churches'.

There are three points in which Mr Dickinson and Dr Richardson are agreed. They both ignore the famous passage in S. Augustine, Confessions ix 6; or rather Mr Dickinson ignores it, while Dr Richardson quotes it only so far as to leave quite a wrong impression of its import. Augustine in fact was seriously exercised as to whether anything so sensuous as the Milanese chant, however 'crabbed and old-fashioned', is lawful in Christian worship, and he can give no more decisive answer than a 'perhaps'; and he tells us incidentally that Athanasius only admitted a chant which was scarcely distinguishable from ordinary intonation. Both writers again allude to ancient prohibitions of singing on the part of the people as distinguished from the canonical clerks; Mr Dickinson interpiets this as a ' saccrdotal 'encroachment, Dr Rirhardson uses it to shew that singing in church has not necessarnly been congregational. Neither seems to realize that people did not always possess Psalters, and largely, I suppose, could not have read them If they had, and consequently that the Psalms and still more Responds and so on were necessarily sung by a Reader or Singer, and the people could only respond with the constant 'acrostich' or refrain, the 'antiphon' in fact. Again, in treating of music in England, neither writer takes any notice of the significance of the $49^{\text {th }}$ Injunction of 1559, which expressly forbids the use of 'music' as distınguished from 'a modest and distinct song so used in all parts of the common prayers in the church, that the same may be as plainly understanded as if it were read without singing', and only allows 'music' 'for the comforting of such as delight in' it, at the beginning or the end of service, i. e. what became the Anthem, and that only in a form which is violated by 'anthems' since Purcell at least, which certainly do not 
'have respect that the sentence of hymn may be understanded and perceived'. The Injunctions of $\mathrm{I}_{559}$ are no doubt quite unimportant ; only the Courts enforce them in matters where their violation is not popular. And anyhow this Injunction lays down an intelligible and reasonable principle, on which musicians would do well to reflect.

F. E. Brightman. 